\title{
A socio-economic analysis of small ruminant breeders' membership relations and organizational effectiveness
}

\author{
Mehmet Ferit CAN \\ Mustafa Kemal University, Faculty of Veterinary Medicine, Animal Health Economics and Management, Hatay, Turkey.
}

Summary: Livestock Producers Organizations have played an important role in sustainable production and rural development. There is a strong relationship between breeders' socio-economics status, membership relations, and organizational success levels. A survey was conducted in the Hatay province in Turkey with 38 small ruminant breeders to investigate organizational responsibilities and satisfaction levels, and to analyze the relationship between their socio-economic status with responsibility and satisfaction. The membership of breeders in any professional organization was found to be $68 \%$, and the most important factor affecting participation in their organizations was bureaucratic reasons. "Basic", "Extended", and "Total" responsibilities of the small ruminant breeders were found to be $16 \%, 24 \%$, and $20 \%$, respectively, and satisfaction levels were "very dissatisfied", "dissatisfied" and "very dissatisfied", respectively. A positive correlation was found between the total responsibility score and membership period $(\mathrm{p}<0.05)$, and a negative correlation was found between total satisfaction score and herd size $(\mathrm{p}<0.01)$. Education level, the most important factor affecting breeders' responsibility, was related to four of the six responsibility components $(p<0.01)$; whereas herd size, the most important factor affecting breeders' satisfaction, was related to three of the eight satisfaction components $(\mathrm{p}<0.05)$. These results indicated that training programs must be arranged to change the attitudes of small ruminant breeders and also management activities of the organization should be closely followed by the breeders to minimize or to prevent some of the management errors and failures.

Key words: Breeder, organization, responsibility, satisfaction, small ruminant.

\section{Küçükbaş hayvan yetiştiricilerinin üyelik ilişkileri ve örgütsel etkinliklerinin sosyo-ekonomik bir analizi}

Özet: Hayvancılık sektöründeki üretici örgütleri sürdürülebilir üretim ve kırsal kalkınmada önemli bir rol oynamaktadır. Yetiştiricilerin sosyo-ekonomik statüleri ile üyelik ilişkileri ve örgütsel başarı düzeyleri arasında güçlü bir ilişki bulunmaktadır. Örgütsel sorumluluk ve memnuniyet düzeyinin araştırılması ve sosyo-ekonomik statü ile sorumluluk ve memnuniyet düzeyleri arasındaki ilişkinin analizi amacıyla Hatay ilinde 38 küçükbaş hayvan yetiştiricisi ile anket çalışması yürütülmüştür. Herhangi bir örgüte üye olanların oranı $\% 68$ olarak bulunmuş, örgüte katılımı belirleyen en önemli faktörün bürokratik nedenler olduğu belirlenmiştir. "Temel", "Genişletilmiş" ve "Toplam” sorumluluk ve memnuniyet düzeyleri sırasılyla \%16, \%24 ve \%20; "hiç memnun değilim", "memnun değilim" ve "hiç memnun değilim” olarak tespit edilmiştir. Toplam sorumluluk skoru ve üyelik süresi arasında pozitif bir korelasyon $(\mathrm{p}<0.05)$, toplam memnuniyet skoru ve sürü büyüklüğü arasında ise negatif bir korelasyon $(\mathrm{p}<0.01)$ bulunmuştur. Yetiştiricilerin sorumluluğunu etkileyen en önemli faktör olan eğitim düzeyi altı sorumluluk bileşeninin dördü ile ilişkiliyken $(\mathrm{p}<0.01)$; memnuniyeti etkileyen en önemli faktör olan sürü büyüklüğü sekiz memnuniyet bileşeninin üçü ile ilişkilidir $(p<0.05)$. Sonuçlar, küçükbaş hayvan yetiştiricilerinin davranış biçimlerinin değiştirilmesi için eğitim programlarının düzenlenmesi gerektiğini, ayrıca bazı yönetimsel hata ve başarısızlıklarının önlenmesi veya minimize edilebilmesi için örgütün yönetim faaliyetlerinin yetiştiriciler tarafından yakın biçimde takip edilmesi gerektiğini göstermektedir.

Anahtar sözcükler: Küçük ruminant, memnuniyet, örgüt, sorumluluk, yetiştirici.

\section{Introduction}

Producers organizations serve the breeders by protecting their economic, judicial, bureaucratic and cultural interests, and aim to help members in maintaining their livestock business viability. Furthermore, they have played an important role in the economic growth, rural development and sustainable production $(3,8,17)$. There are many agricultural and producers organizations around the world, including in Turkey, founded by the state or by civil society for social, political, technical, and economic reasons.

In Turkey, the sheep and goat breeding enterprises has been ignored by the state throughout the history of Turkey and a number of them have followed a declining trend since the early 1980s. Many factors have contributed to this situation, among which are low genetic potential 
of the indigenous breeds, inappropriate breeding strategies, a decrease in the area covered by pastures and rangelands, better education and demand for high status jobs, and unfavorable market conditions for sheep and goat production (13). Moreover, low levels of organizational responsibility and satisfaction among breeders might have adversely affected the sheep and goat industry (7).

Despite the existence of many organizations for small ruminant breeders (SRB) in Turkey, they have not been successful in respect to financial, economic, and political contributions. One of the important reasons for this failure is managerial weaknesses in organizations and a lack of collaboration and organizational awareness amongst the members $(6,7)$.

The aims of this study to investigate organizational responsibilities and satisfaction levels of $\mathrm{SRB}$, and to analyze the relationship between socio-economic characteristics, responsibility, and satisfaction components. The results of this study can provide positive contributions to small ruminant organizations and policymakers towards a better understanding of and solution to some of the important organizational problems.

\section{Materials and Methods}

Data collection: The required data were obtained via face-to-face questionnaires carried out between May 2012 and October 2012, with a total of 38 small ruminant breeders who were randomly selected in twelve different villages of the Hatay province in Turkey. Pre-questionnaire forms were prepared and conducted with breeders to remove any possible deficiencies and to produce more useful data. The final questionnaire form consisted of a total of twenty-two different questions that include breeders' personal information, member preferences, social, democratic, and legal responsibilities, and satisfactions. The responsibilities and satisfactions components were prepared according to six and eight different criteria, respectively.

Data evaluation: In this study, organizations were evaluated by their services and activities with the Likert five-point satisfaction scale, and legal and democratic performance of the small ruminant breeders (organizational responsibilities/commitments) were evaluated with the responsibility items. Responsibilities and satisfactions were evaluated according to the "basic", "extended", and "total" levels. Basic and extended responsibility and satisfaction levels of breeders were measured by using three and four different items, respectively. For total responsibility and satisfaction levels, all of the items were taken into account.

In this study, basic responsibility level was considered the minimum requirements of being a member and means that members are able to fulfill it routinely. Extended responsibility level means that members are able to fulfill their democratic and social role in an organization. Total responsibility means that members have a high responsibility and have a high level of awareness about their legal rights and democratic role. Basic satisfaction level was considered the minimum standard to achieving the organizational goals. In other words, it means whether an organization is able to fulfill the basic needs of its members or not. Extended satisfaction level means that social and cultural expectations of the members can be fulfilled by their organizations.

The data were tested for normal distribution with the Shapiro-Wilk test, as it is more appropriate than the Kolmogorov-Smirnov test, especially for sample sizes less than $50(2,18)$. Spearman correlations were calculated for total responsibility and total satisfaction scores, and breeders' characteristics. Fisher's exact test was used to examine the significance between breeders' socio-economic factors and their responsibility and satisfaction components. All of the statistical analyses were performed with the aid of the SPSS-15.0 statistical package program.

\section{Results}

Characteristics of the SRB: The findings related to age, work experience, membership period, herd size, educational level, and income level of SRB who are members of different organizations and non-members are given in Table 1. The distribution of breeders among organizations and the primary reason for being a member in the organizations are given in Figure 1.

Table 1: Descriptive statistics related to members or non-members to organizations.

Tablo 1: Örgütlere üye ve üye olmayanlara ilişkin tanımlayıcı istatistikler.

\begin{tabular}{|c|c|c|c|}
\hline Characteristics & $\begin{array}{c}\text { Descriptive } \\
\text { Statistics }\end{array}$ & $\begin{array}{c}\text { Members }^{\mathrm{a}} \\
(\mathrm{n}=26)\end{array}$ & $\begin{array}{c}\text { Non- } \\
\text { members } \\
(\mathrm{n}=12)\end{array}$ \\
\hline Age (year) & $\bar{x} \pm S d$ & $52.76 \pm 11.96$ & $42 \pm 10.29$ \\
\hline $\begin{array}{l}\text { Work Experience } \\
\text { (year) }\end{array}$ & $\bar{x} \pm S d$ & $19.76 \pm 14.29$ & $20 \pm 14.50$ \\
\hline $\begin{array}{l}\text { Membership } \\
\text { Period (year) }\end{array}$ & $\bar{x} \pm S d$ & $7.43 \pm 9.34$ & - \\
\hline Herd Size (head) & $\bar{x} \pm S d$ & $128.17 \pm 107.36$ & $96 \pm 68.67$ \\
\hline Education Level & Median & $1(1-4)^{\mathrm{b}}$ & $1(1-4)^{b}$ \\
\hline Income Level & Median & $2(1-4)^{c}$ & $1(1-4)^{\mathrm{c}}$ \\
\hline
\end{tabular}

a Includes Small Ruminant Breeders' Association, Chambers of Agriculture, and Cooperative.

b 1 ,elementary school; 2, middle school; 3, high school; 4, undergraduate.

c $1, \$ 0-455$ (\$455 is the current monthly bottom wage for the year of 2013 in Turkey); 2, \$455- 1000; 3, \$1000-1500; 4, more than $\$ 1500$.

The breeder members' educational level in the Sheep and Goat Breeders' Association (SGBA), Chambers of Agriculture (CA), Cooperative (C), and non-members (NM) were $66 \%, 67 \%, 100 \%$, and $67 \%$ for primary 


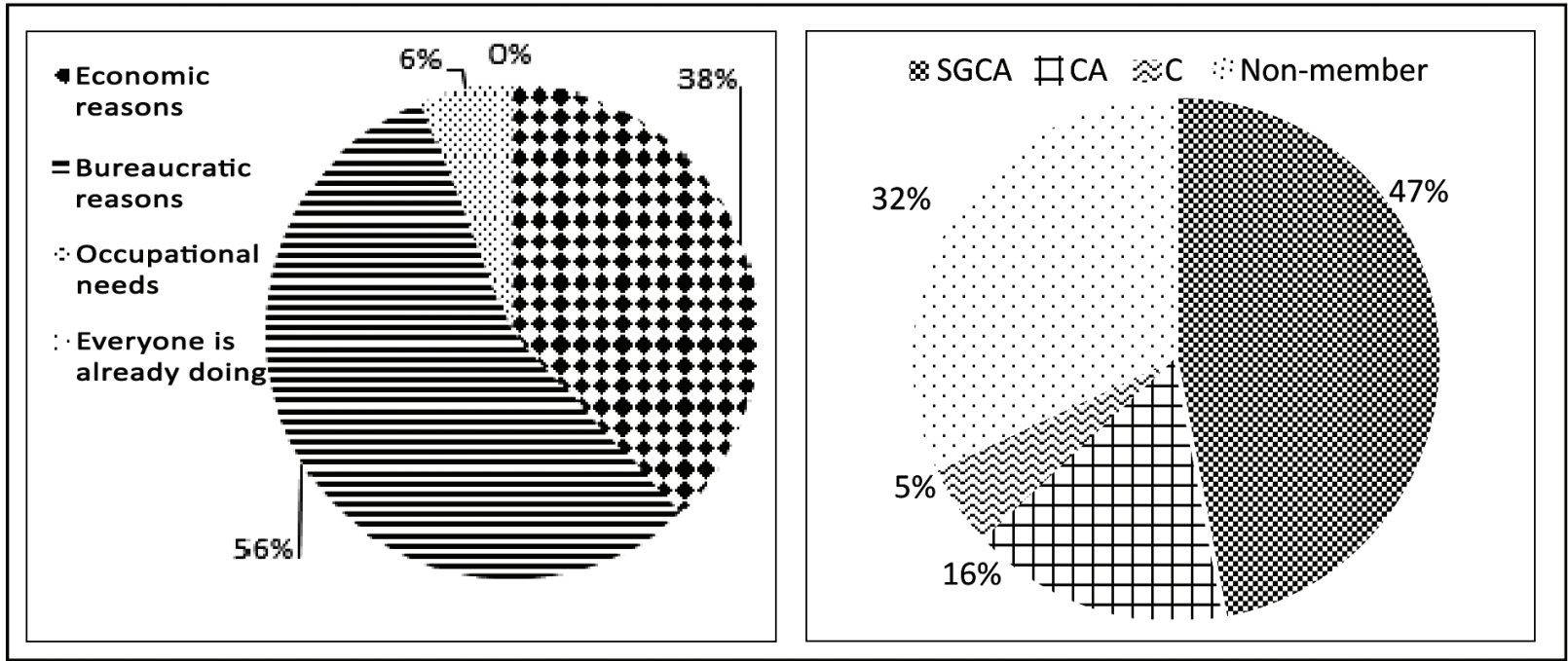

Figure 1: The distribution of membership and main reasons to be a member of organization.

Şekil 1: Üyelik dağılımı ve örgüte üye olmanın temel nedenleri.

Table 2: Organizational responsibilities and satisfaction levels of the small ruminant breeders.

Tablo 2: Küçükbaş hayvan yetiştiricilerinin örgütsel sorumluluk ve memnuniyet düzeyleri.

\begin{tabular}{|c|c|c|c|c|c|c|c|}
\hline \multicolumn{2}{|c|}{ Responsibility Components } & $\mathrm{n}$ & $\%$ & \multicolumn{2}{|c|}{ Satisfaction Components } & Mean & Scale \\
\hline \multicolumn{2}{|c|}{ I. Knowing organizational law } & 3 & 12 & \multicolumn{2}{|c|}{ I. Required input supply } & 1 & VD \\
\hline \multicolumn{2}{|c|}{ II. Reading the contract } & 3 & 12 & \multicolumn{2}{|c|}{ II. Marketing of products } & 1 & VD \\
\hline \multicolumn{2}{|c|}{ III. Participate in voting } & 6 & 23 & \multicolumn{2}{|c|}{ III. Official proceedings } & 3 & NSD \\
\hline \multicolumn{2}{|c|}{ IV. To be candidate for elections } & 0 & 0 & \multicolumn{2}{|c|}{ IV. Occupational information } & 1 & VD \\
\hline \multicolumn{2}{|c|}{ V. Knowing the management board } & 17 & 65 & \multicolumn{2}{|c|}{ V. Regular farm visits } & 1 & VD \\
\hline \multirow{3}{*}{\multicolumn{2}{|c|}{ VI. To be aware of the decisions }} & 2 & 8 & \multicolumn{2}{|c|}{ VI. Meeting new breeders } & 1 & VD \\
\hline & & & & \multicolumn{2}{|c|}{ VII. Speed of services } & 3 & NSD \\
\hline & & & & \multicolumn{2}{|c|}{ VIII. Level of trust } & 3 & NSD \\
\hline Basic $^{\mathrm{a}}$ & Extended $^{\mathrm{b}}$ & \multicolumn{2}{|c|}{ Total $^{\mathrm{c}}$} & Basic $^{d}$ & Extended $^{\mathrm{e}}$ & \multicolumn{2}{|c|}{ Total $^{\mathrm{c}}$} \\
\hline $16 \%$ & $24 \%$ & & & VD & $\mathrm{D}$ & \multicolumn{2}{|c|}{ VD } \\
\hline
\end{tabular}

VD, very dissatisfied; D, dissatisfied; NSD, neither satisfied nor dissatisfied; S, Satisfied; VS, very satisfied.

${ }^{a}$ Responsibility components of I, II and III.

${ }^{\mathrm{b}}$ Responsibility components of IV, V and VI.

${ }^{\mathbf{c}}$ Include all of the responsibility/satisfaction components.

${ }^{\mathrm{d}}$ Satisfaction components of I, II, III and IV.

${ }^{\mathrm{e}}$ Satisfaction components of V, VI, VII and VIII.

school, respectively; and $21 \%, 17 \%, 0 \%$, and $0 \%$ for undergraduate, respectively. The income levels of breeder members in SGBA, CA, C, and NM was $62 \%$, $50 \%, 50 \%$, and $100 \%$ for $0-\$ 455$, respectively; and $7 \%$, $10 \%, 0 \%$, and $0 \%$ for more than $\$ 1500$, respectively.

Findings regarding the responsibility and satisfaction levels: The findings related to breeders' responsibilities and satisfactions toward their professional organizations according to the basic, extended, and total levels are given in Table 2.

Statistical analysis of the socio-economic factors: Significant differences were found between members and $\mathrm{NM}$, in terms of their age $(\mathrm{t}(36)=2.313, \mathrm{p}<0.05)$ and there were no significant differences with respect to income level, education level, and work experience. A positive correlation was found between total responsibility score and membership period ( $r h o(24)=0.507, \mathrm{p}<0.05)$, and a negative correlation was found in the total satisfaction score and herd size (rho (24) $=-0.655$, $\mathrm{p}<0.01)$. An analysis of the social and economic factors together with responsibility and satisfaction components of breeders is given in Table 3 .

\section{Discussion and Conclusion}

The principal aims of the SRB organization are to assist and encourage breeding, maintain purity, improve the various breeds, and provide information on care and breeding. The chamber of agriculture and cooperatives also play a crucial role in supporting the activities of the livestock sector, in promoting rural development, and in 
Table 3: Analysis of social and economic factors together with responsibility and satisfaction components. Tablo 3: Sosyo-ekonomik faktörlerin sorumluluk ve memnuniyet bileşenleriyle beraber analizi.

\begin{tabular}{|c|c|c|c|c|c|c|}
\hline & Components & Age & $\begin{array}{l}\text { Membership } \\
\text { Period }\end{array}$ & $\begin{array}{l}\text { Education } \\
\text { Level }\end{array}$ & $\begin{array}{l}\text { Income } \\
\text { Level }\end{array}$ & $\begin{array}{l}\text { Herd } \\
\text { Size }\end{array}$ \\
\hline \multirow{6}{*}{ 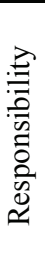 } & Knowing organizational law & $42.716^{*}$ & NR & $9.237 * *$ & NR & NR \\
\hline & Reading the contract & NR & NR & $9.237 * *$ & NR & NR \\
\hline & Participate in voting & NR & $13.877^{*}$ & NR & NR & NR \\
\hline & To be candidate for elections & $33.018^{*}$ & NR & NR & NR & NR \\
\hline & Knowing the management board & NR & NR & $5.894 *$ & NR & NR \\
\hline & To be aware of the decisions & NR & NR & $6.813 *$ & $7.449 *$ & NR \\
\hline \multirow{8}{*}{ 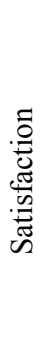 } & Required input supply & NR & NR & NR & NR & $50.252 *$ \\
\hline & Marketing of products & NR & $25.854 *$ & NR & NR & $32.519 *$ \\
\hline & Official proceedings & NR & NR & NR & NR & NR \\
\hline & Occupational information & NR & NR & NR & NR & NR \\
\hline & Regular farm visits & NR & NR & NR & NR & NR \\
\hline & Meeting new breeders & NR & NR & NR & NR & NR \\
\hline & Speed of services & NR & NR & NR & $10.102 * *$ & NR \\
\hline & Level of trust & NR & $44.627 * * *$ & NR & NR & $53.815^{*}$ \\
\hline
\end{tabular}

$*=\mathrm{p}<.05 ; * * \mathrm{p}<.01 ; * * * \mathrm{p}<.001 ;\left(\mathrm{X}^{2}\right.$, Fisher's exact test $)$

NR, No relationship was found between factors.

maintaining sufficient market power. Despite the above mentioned objectives, in this study, bureaucratic reasons were found as the most important factor affecting breeders' decision whether to participate in the membership of organizations or not. In Turkey, a majority of the breeders believe that organizational activities have not been effectively executed, with the exception of providing required official documents or bureaucratic issues.

The results of this study make it possible to compare small ruminant breeders' satisfaction levels and responsibilities to each other, and also helped to understand organizational activities from two different perspectives. Basic, extended, and total responsibilities and satisfaction levels clearly indicated that both breeders and organizations have not fulfilled their legal, democratic, and social responsibilities, and they have behaved extremely irresponsibly. In our opinion, the solution of this problem can be quite difficult and can be a time-consuming process for Turkey.

Although significant differences were found between members and NM in terms of their age, it is surprising that no significant differences were found in terms of their education or income levels. A negative correlation was found between herd size and total satisfaction score. A positive correlation between membership period and total responsibility score indicated that breeders having a longer membership period have taken more responsibility. Education level is considered to be the most important characteristic of breeders for responsibilities, due to the fact that it was found to be related to four of the six responsibility components; likewise, herd size is considered to be the most important characteristic for satisfaction due to the fact that it was found to be related to three of the eight satisfaction components.

Although the results of this study and official statistics clearly reveal a great number of cattle and small ruminant breeders are members of any professional organization in Turkey, management and financial problems of organizations could not be solved properly until now. Can and Sakarya (2012) indicated that the success of an organization largely depends on a number of external factors including economic, political, and social factors, usually not under the control of the organization, as well as internal factors, which are more important for the organization, including members' attitudes and organizational management (6). In accordance with our results, it was found that organizational responsibilities and satisfaction levels of cattle breeders were quite low in Hatay, Turkey (7).

It is important to highlight that there are two types of sheep and goat farmers. The first are professional farmers, who live in developed countries, and have realized that their future depends on themselves and their own decisions (13). Furthermore, some of the developed countries such as Unites States, Canada, and Israel, have a well-organized goat sector, which is very active with magazines, fairs, and innovative products. Europe is the only continent where goat milk has such an economic importance and organization, and it owns only $2.5 \%$ of the world goat herd, but produces $18 \%$ of the world goat milk (9). The second type are those farmers who are live in developing countries and are often among the poorest classes on the social scale, not yet conscious of this fact or adopted this approach only very slowly (15). Moreover, in developing countries, including Turkey, 
sheep and goat farmers are generally reluctant to adopt novel husbandry methods to improve their income (13), and they have been faced by socio-economic constraints, which are costly, and the availability of credit, husbandry skills, and marketing infrastructure $(4,20,21)$.

It is indicated that the most influential factors of technical efficiency are membership in farmer organizations and the participatory rate in collective actions organized by farmer organizations (12). The leading factors deterring farmer's participation were determined as a lack of partnership culture, and a lack of sufficient power in the cooperatives to the assigned tasks. Another noteworthy finding of the study is a lack of harmony between the objectives of villagers and the cooperatives (1). Without compulsory membership, organizations must appeal to members and provide valued services and opportunities (18).

It was reported that farmers' intentions were mainly associated with the characteristics of their farms, and farmers' beliefs and social referents play an important role in farmers' decisions to use improved grassland on their farms (11). Moreover, it is indicated that farmer characteristics are related to the distribution of animal infections and membership in a farmers' organization is a protective factor for border diseases in small ruminant herds. Farmers belonging to professional associations had the best farms in terms of infrastructure, management, animal care, and health status because they had better access to information about good farming practices (14).

Responsibility and commitment have a great impact on the successful performance of an organization. They were defined as consisting of three components: (I) an identification with the goals and values of the organization, (II) a desire to belong to the organization, and (III) a willingness to display effort on behalf of the organization (16). Member commitment is linked to the cooperative's ability and this feedback relationship suggested member commitment may be subject to either a virtuous upward circle or a vicious downward spiral (10).

Another important issue is the role of women farmers in the small ruminant sector and organizational effectiveness. Farmers' organizations represent another way for rural women to gain access to technology, information, and training. However, participation in such organizations is restricted for women by custom and land tenure (5). It is also indicated that the importance of women's contribution to agricultural economic activities has gone largely unrecognized and women farmers continue to have limited access to technical assistance, training, or credit (19).

There is a strong relationship between breeders' socio-economics status and their perception when considering organizational success (7). Therefore, to change the perception and attitudes of breeders' farm visits, regular periodic meetings, and timely provision of services should be arranged and encouraged by organizations or governments. Education and training play a crucial role in influencing the members' democratic participation, and occupational and technical training require greater attention. Moreover, non-members should be encouraged to be a member of the organizations.

The key component of the competitive, innovative, and sustainable rural development is the availability of democratic and powerful organizations, especially in developing countries, including Turkey $(6,7,8)$. In our opinion, unless the small ruminant organizations have a high rate of democratic participation, input supply, and marketing, which are the most important financial problems of breeders in Turkey, these issues cannot be properly solved.

\section{References}

1. Alambeigi A, Zarifian S, Rezaei A (2008): Determinants of cattle farmers participation in farmers organization in Hamadan province of Iran. Journal of Agriculture and Social Research, 8, 125-133.

2. Baghban AA, Younespour S, Jambarsang S, Yousefi M, Zayeri F, Jalilian FA (2013): How to test normality distribution for a variable: a real example and a simulation study. Journal of Paramedical Sciences, 4, 73-77.

3. Bernard C (1994): The Function of Executive. Cambridge, Harward University Press, Cambridge, US.

4. Bett HC, Bett HK, Kahi AK, Peters KJ (2009): Evaluation and effectiveness of breeding and production services of dairy goat farmers in Kenya. Ecological Economics, 68, 2451-2460.

5. Budak DB, Darcan N, Kantar M (2005): Women farmers and extension services in small ruminant production in mountain areas of Turkey. Journal of Arid Environments, 62, 507-515.

6. Can MF, Sakarya E (2012): Dünya ve Türkiye'de Tartm ve Hayvancllı Kooperatiflerinin Tarihsel Gelişimi, İktisadi Önemi ve Mevcut Durumu. Vet Hekim Der Derg, 83, 27-36.

7. Can MF (2013): The effect of cattle breeders' socio-economic status on responsibility and satisfaction toward their organizations (ID: 365). The 31st World Veterinary Congress. 17-20 September, 2013, Prague, Czech Republic.

8. Çetin B (2010): Agricultural Economics. 1st ed. Dora Publications, Bursa, Turkey.

9. Dubeuf JP (2005): Structural, market and organizational conditions for developing goat dairy production systems. Small Ruminant Research, 60, 67-74.

10. Fulton M, Giannakas G (2001): Organizational commitement in a mixed oligopoly: Agricultural cooperatives and investor-owned firms. Amer. J. Agr. Econ, 83, 1258-1265.

11. Garcia CGM, Dorward P, Rehman T (2013): Factors influencing adoption of improved grassland management by small-scale dairy farmers in central Mexico and the imlications of future research on small holder adoption in developing countries. Livestock Science, 152, 228-238.

12. Gedara KM, Wilson C, Pascoe S, Robinson T (2012): Factor affecting technical efficiency of rice farmers in 
village reservoir irrigation systems of Sri Lanka. Journal of Agricultural Economics, 63, 627-638.

13. Gürsoy O (2006): Economics and profitability of sheep and goat production in Turkey under new support regimes and market conditions. Small Ruminant Research, 62, 181-191.

14. Mainer-Jaime RC, Vazquez-Boland JA (1999): Associations of veterinary services and farmer characteristics with the prevalences of brucellosis and border disease in small ruminants in Spain. Preventive Veterinary Medicine, 40, 193-205.

15. Morand-Fehr P, Boyazoğlu J (1999): Present state and future outlook of the small ruminant sector. Small Ruminant Research, 34, 175-188.

16. Nehmeh R (2009): What is organizational commitment, why should managers want it in their workforce and is there any cost effective way to secure it? SMS Working Paper. Issue 05, 2009. ISSN 1662-761X. Swiss Management Centre.

17. Ortmann GF, King RP (2007): Agricultural Cooperatives I: History, Theory and Problems. Agrekon, 46, 40-68.

18. Royston JP (1981): An extension of Shapiro and Wilk's $W$ test for normality to large Samples. Appl. Statist, 31, 115124.
19. Sinn R, Ketzis J, Chen T (1999): The role of woman in the sheep and goat sector. Small Ruminant Research, 34, 259-269.

20. Upton M (2004): The role of livestock in economic development and poverty reduction. Food and Agricultural Organization (FAO), Pro-Poor Policy Initiative (PPLPI). Working Paper, vol. 10, p. 57. Rome, Italy.

21. Wollny CBA (2003): The need to conserve farm animal genetic resources in Africa: should policy makers be concerned? Ecol. Econ, 45, 341-351.

Geliş tarihi: 07.05.2013 / Kabul tarihi: 18.11.2013

Address for correspondence:

Mehmet Ferit Can

Mustafa Kemal University,

Faculty of Veterinary Medicine,

Animal Health Economics and Management,

Hatay, Turkey.

feritcan@mku.edu.tr,+903262455845 (1519) 